DOI: https://doi.org/10.24127/ajpm.v9i4.3132

\title{
PENGEMBANGAN MULTIMEDIA INTERAKTIF PADA MATERI HIMPUNAN BERBASIS PUZZLE DENGAN PENDEKATAN KONTEKSTUAL
}

\author{
Firda Alfiana Patricia ${ }^{1}$, Kenys Fadhilah Zamzam² \\ ${ }^{1,2}$ Pendidikan Matematika, IKIP Budi Utomo Malang, Jawa Timur, Indonesia \\ ${ }^{*}$ Corresponding author \\ E-mail: $\quad$ firdaalfianapatricia1985@ gmail.com $^{1)}$ \\ kenysfz@gmail.com $^{2)}$
}

Received 02 October 2020; Received in revised form 23 December 2020; Accepted 27 December 2020

\begin{abstract}
Abstrak
Penggunaan multimedia interaktif dalam proses pembelajaran dapat membangkitkan motivasi siswa dalam belajar. Tujuan dikembangkan multimedia interaktif ini adalah menghasilkan media pembelajaran untuk anak SMP pada materi himpunan berbasis puzzle dengan pendekatan kontekstual. Model pengembangan adalah model pengembangan ADDIE dimana terdiri dari lima fase yaitu fase analisis, fase desain, fase pengembangan, fase implementasi serta fase evaluasi. Pada pengembangan ini diuji tingkat validitas dan tingkat keefektifan dari multimedia interaktif yang dikembangkan. Subyek penelitian ini adalah 25 siswa SMP kelas 7. hasil dari rata-rata validatas ketiga validator adalah 3,40 dimana masuk dalam kategori valid untuk diujicobakan, hasil ujicoba menunjukkan persentase ketuntasan siswa sebesar $78,2 \%$ dan tingkat persentase respon siswa adalah $84,5 \%$ berarti siswa memberikan respon positif. Secara menyeluruh maka multimedia interaktif pada materi himpunan berbasis puzzle dengan pendekatan kontekstual efektif untuk digunakan dalam proses pembelajaran
\end{abstract}

Kata kunci: kontekstual; multimedia; puzzle.

\begin{abstract}
The use of interactive multimedia in the learning process can arouse student motivation in learning. The purpose of developing this interactive multimedia is to produce learning media for junior high school children on puzzle-based set material with a contextual approach. The development model is the ADDIE development model which consists of five phases, namely the analysis phase, the design phase, the development phase, the implementation phase and the evaluation phase. In this development, the level of validity and effectiveness of interactive multimedia was tested. The subjects of this study were 25 grade 7 junior high school students. The result of the average validation of the three validators was 3.40 which was included in the valid category to be tested, the test results showed the percentage of student completeness was $78.2 \%$ and the percentage level of student response was $84.5 \%$ means students give a positive response. Overall, interactive multimedia on puzzle-based set material with a contextual approach is effective for use in the learning process
\end{abstract}

Keywords: contextual; multimedia; puzzle.

This is an open access article under the Creative Commons Attribution 4.0 International License

\section{PENDAHULUAN}

Perkembangan teknologi berhubungan erat dengan proses belajar mengajar yaitu sebagai media yang efektif dan efisien dalam pembelajaran. Penggunaan teknologi sebagai media pembelajaran dapat mempermudah guru untuk mendapatkan ataupun me- nyampaikan informasi (materi) pembelajaran sehingga mampu meningkatkan pemahaman siswa. Selain itu penggunaan media dalam proses pembelajaran di dalam kelas dapat membangkitkan motivasi siswa dalam belajar. (Kurnia, 2015) menyatakan penerapan media pembelajaran berupa 
media visual memberikan pengaruh yang positif dimana dapat dibuktikan melalui hasil dari belajar siswa yang terus meningkat setelah mendapatkan perlakuan pembelajaran menggunakan media pembelajaran tersebut.

Multimedia interaktif adalah gabungan beberapa media seperti audio, gambar, video, teks ataupun animasi dimana bersifat interaktif yang bertujuan menyampaikan informasi. (Ivers, 2010) menyatakan multimedia merupakan gabungan penggunaan dari beberapa media yang bertujuan untuk menyampaikan informasi. (Istiqlal, 2017) menyatakan multimedia interaktif merupakan solusi sebagai sumber belajar mandiri baik dirumah maupun disekolah yang mampu meningkatkan pemahaman siswa terhadap materi yang disampaikan. Sejalan dengan pernyataan (Pranata et al., 2015) yaitu multimedia merupakan sebuah alat bantu instruksional untuk siswa, sebagai tutorial seperti simulasi dan media pembelajaran sehingga membantu kemandirian siswa.

Beberapa keuntungan dari multimedia interaktif yang digunakan sebagai media pembelajaran menurut (Nopriyanti, 2015) antara lain sebagai berikut: 1) menjadi media pembelajaran yang mampu menyimpan informasi dengan baik; 2) desain dari pembelajarannya ditunjukkan untuk siswa dengan berbagai ragam karakteristik belajar; 3) secara langsung dikhususkan untuk domain pembelajaran secara efektif; 4) pembelajaran yang disajikan realistis; 5) mampu meningkatkan motivasi siswa dalam belajar; 6) siswa dituntut untuk lebih interaktif; 7) proses kegiatan pembelajarannya bersifat individual; 8) mempunyai konsistensi pada materi yang diberikan; 9) terbentuknya pengendalian dari siswa pada kecepatan belajarnya pada masing-masing individu. (Kurniawati, 2018) dalam penelitiannya mengatakan bahwa media pembelajaran berbasis multimedia interaktif mampu meningkatkan pemahaman konsep mahasiswa. Selain itu pembelajaran dalam bentuk multimedia interaktif mampu meningkatkan hasil belajar matematika siswa (Andinny, 2016). Salah satu bentuk pengembangan multimedia dapat berupa permainan.

Bermain merupakan suatu aktivitas yang banyak disukai semua kalangan terutama anak-anak. (Gray, 2011) menyatakan bahwa anak-anak sudah didesain secara alami agar bermain untuk menambahkan pengalaman dan pengetahuan. Akan tetapi masih sedikit orang tua yang melihat bermain merupakan sarana dalam belajar. Konteks permainan dalam penelitian ini adalah sebuah aplikasi atau perangkat lunak yang berupa media interaktif yang akan dimainkan pada perangkat keras elektronik seperti ponsel genggam yang bertujuan untuk meningkatkan kemampuan berpikir siswa serta kemampuan berbahasa siswa. (Yunanto, 2016) permainan digital yang merujuk pada game yang dimainkan oleh perangkat lunak mampu melatih konsentrasi anak, mengatasi keterbatasan waktu dan mampu mengatasi keterbatasan Bahasa. (Heru, 2018) mengatakan bahwa multimedia dalam bentuk game pembelajaran untuk anak SMP mampu meningkatkan hasil belajar dan pemahaman siswa. Sejalan dengan (Panjaitan, 2020) dalam penelitiannya memberikan kesimpulan bahwa multimedia interaktif berbasis game edukasi sebagai media pembelajaran dapat meningkatkan pemahaman konsep sistem pernapasan. Hal ini sesuai dengan pernyataan 
(Akbar W., 2017) yaitu dalam proses pembelajaran dimana materi disajikan dalam bentuk multimedia interaktif yang dilengkapi dengan simulasi soal serta gambar maupun animasi membuat materi yang disampaikan mudah dimengerti. Selain itu dalam penelitiannya (Purnomo, A, 2017) menyatakan banyak siswa menyukai game sebagai media pembelajaran karena lebih mudah untuk dimainkan dan mudah dimengerti.

$$
\text { English Oxford Living }
$$

Dictionaries (2017) menjelaskan puzzle berarti suatu game, mainan, atau permainan yang didalamnya memuat masalah yang akan diselesaikan dimana bertujuan untuk mengasah kecerdasan dari pemainnya. Menurut (Clontz, 2018) terdapat delapan jenis permainan puzzle antara lain sebagai berikut: 1) mechanical puzzle; 2) logic puzzle; 3) math puzzle; 4) cryptic puzzle; 5) word puzzle; 6) trivia puzzle; 7) riddles; 8) pattern guessing. Dalam penelitian ini dipilih jenis permainan math puzzle dimana puzzle ini secara umum berbentuk permasalahan matematika.

Berdasarkan observasi awal dan wawancara guru SMP Tarbiyatus Shyban diperoleh bahwa siswa SMP kelas 7 menunjukkan hasil belajar yang rendah pada materi himpunan ini berarti pemahaman siswa terhadap konsep himpunan masih rendah padahal himpunan merupakan materi dasar untuk mempelajari materi yang lebih lanjut. Dalam kehidupan sehari-hari, kita tidak bisa lepas dari peranan himpunan dalam menyelesaikan masalah karena mempelajari himpunan mampu mengasah kemampuan logika dan berpikir logis. (Rejeki et al., 2019) mengganggap himpunan merupakan materi yang sangat penting karena himpunan adalah dasar dalam mempelajari aljabar sehingga siswa diharapkan dapat memahami serta menguasai materi ini. Temuan kesulitan belajar siswa pada materi himpunan adalah tentang pemahaman konsep (Milla, 2018). Untuk itu guru dituntut untuk menemukan solusi untuk memudahkan siswa dalam mempelajari dan memahami konsep himpunan dengan acuan rambu-rambu kurikulum. Pada rambu-rambu kurikulum pembelajaran matematika disebutkan bahwa untuk mengajarkan konsep matematika dimulai dari permasalahan yang sesuai dengan kondisi atau masalah kontekstual. (Mulhamah, 2016) dalam penelitiannya menunjukkan efektifitas penerapan pembelajaran kontekstual mampu meningkatkan pemahaman konsep, kemampuan siswa sebagai problem solver meningkat, peningkatan prestasi serta kualitas pembelajaran. Sejalan dengan penelitian (Fauziah, 2019) bahwa pendekatan pembelajaran kontekstual berbasis multimedia memberikan pengaruh yang besar dalam meningkatkan kemampuan pemahaman matematis siswa SMP. (Surachman, 2014) mengatakan multimedia interaktif berbasis kontekstual dapat meningkatkan penguasaan konsep dan keterampiulamn berpikir kritis siswa. Berdasarkan paparan diatas maka dalam penelitian ini dikembangkan multimedia interaktif pada materi himpunan berbasis puzzle dengan pendekatan kontekstual. Tujuan dari penelitian ini adalah mengembangkan perangkat lunak sebagai media pembelajaran yang efektif sehingga mampu meningkatkan pemahaman konsep pada materi himpunan.

\section{METODE PENELITIAN}

Penelitian pengembangan ini menggunakan metode penelitian Research and Development (R\&D). 
Subyek dalam penelitian ini adalah 25 siswa kelas 7 SMP Tarbiyatus Shyban. Model pengembangan yang digunakan adalah model pengembangan ADDIE. (Arofah \& Cahyadi, 2019) menggolongkan model ADDIE dalam lima fase yaitu fase analisis, fase desain, fase pengembangan, fase implementasi serta fase evaluasi. Adapun prosedur penelitian model pengembangan ADDIE yang disesuaikan dengan penelitian pengembangan ini seperti pada Gambar 1.

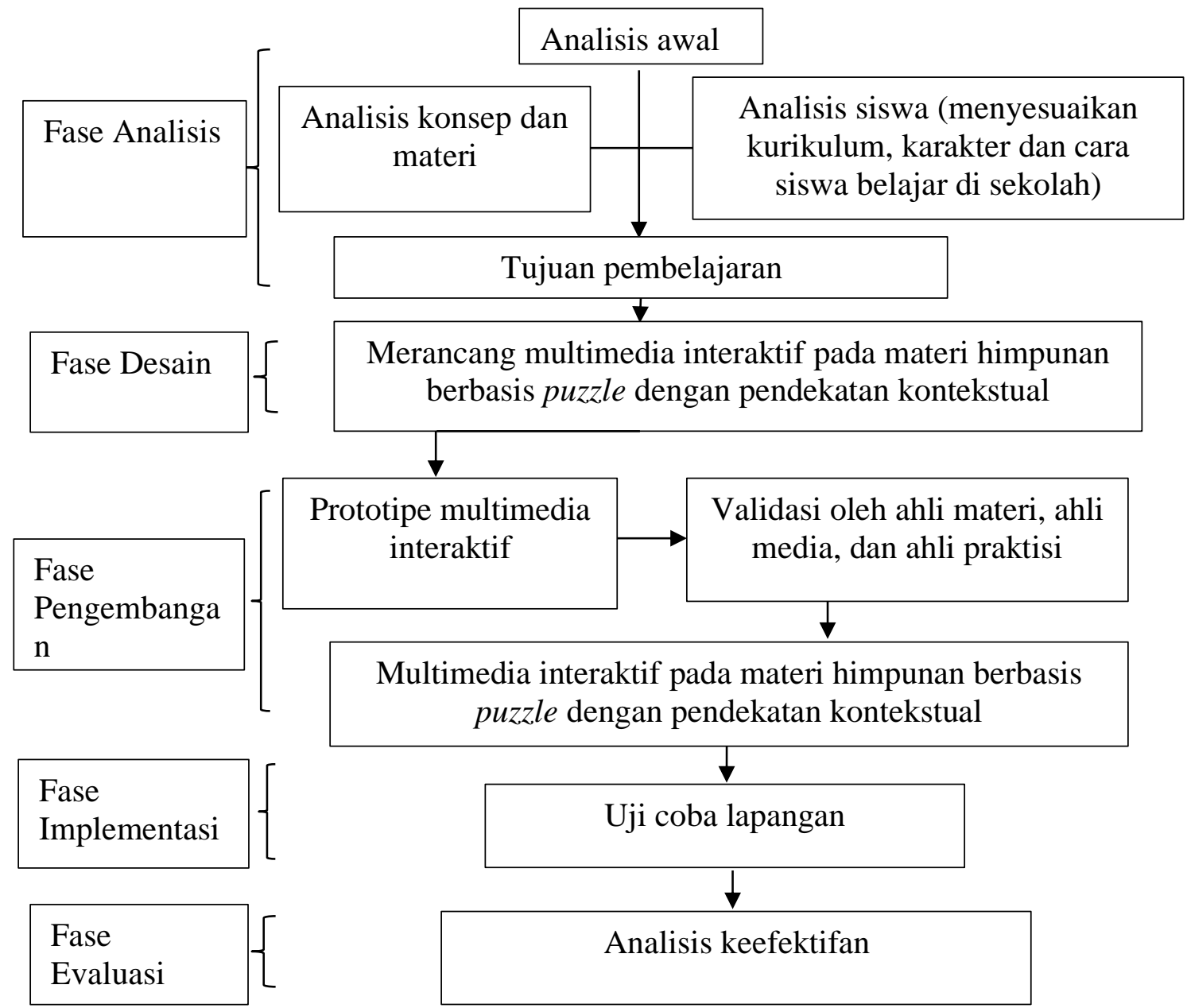

Gambar 1. Prosedur penelitian dengan model pengembangan ADDIE.

Instrumen yang digunakan dalam pengumpulan data pada penelitian ini adalah lembar validasi untuk mengukur validitas multimedia yang dikembangkan, tes hasil belajar dan analisis respon siswa untuk mengukur efektifitas. Teknik pengumpulan data pada penelitian ini bertujuan untuk mengetahui tingkat keefektifan multimedia interaktif yang dikembangkan. Pada awal fase implementasi dilakukan uji coba skala kecil yaitu sebanyak 3 orang siswa dengan kriteria 1 orang siswa berkemampuan tinggi, 1 orang siswa berkemampuan sedang, dan 1 orang siswa berkemampuan rendah. Kriteria siswa didasarkan pada hasil rapor dan rekomendasi guru kelas. Tujuan diadakannya uji coba skala kecil adalah untuk mengetahui keterbacaan dari multimedia interaktif yang dikembangkan. Setelah melakukan revisi dari hasil uji kelompok kecil maka dilakukan uji 
coba kelompok besar sebanyak 25 siswa kelas 7 SMP Tarbiyatus Shyban.

Teknik analisis data pada penelitian ini menggunakan teknik analisis data deskriptif. Untuk mendapatkan suatu prototipe dari suatu perangkat pembelajaran maka diperlukan sebuah uji kualitas terhadap perangkat pembelajaran yang dikembangkan yaitu menguji tingkat dari kevalidan dan keefektifan (Rochmad, 2012). Mengacu pada pernyataan tersebut maka dalam penelitian ini analisis yang digunakan adalah analisis validitas dan analisis efektifitas multimedia interaktif pada materi himpunan berbasis puzzle dengan pendekatan kontekstual.

Analisis validitas dilakukan oleh tiga validator yaitu validator media, validator materi, dan validator praktisi dimana dalam penelitian ini sebagai praktisi adalah guru kelas 7 SMP Tarbiyatus Shyban. Kriteria penilaian kevalidan menggunakan kriteria penilaian (Rasyid et al., 2016) dimana terdiri dari tiga kriteria yaitu 1) $1 \leq \mathrm{RTV}<2$ maka multimedia tidak valid; 2) $2 \leq \mathrm{RTV}<3$ maka multimedia cukup valid; 3) $3 \leq \mathrm{RTV} \leq 4$ maka multimedia valid. Aspek-aspek yang dinilai terdiri dari kelayakan isi maupun tampilannya.

Analisis keefektifan multimedia interaktif pada materi himpunan berbasis puzzle dengan pendekatan kontekstual dinilai dari data hasil belajar siswa dan analisis respon siswa. Data hasil belajar siswa dilihat dari ratarata nilai posttest pada akhir pembelajaran dimana ketuntasan belajar siswa menggunakan multimedia interaktif mencapai tingkat penguasaan terhadap materi minimal sebesar $80 \%$ siswa mendapatkan skor 75 dari skor maksimal 100 (Rasyid et al., 2016). Sedangkan angket respon siswa dilihat dari persentase nilai rata-rata respon siswa dimana menurut (Rasyid et al., 2016) kriteria respon siswa terdiri dari empat kriteria yaitu 1) RS<50\% maka respon siswa tidak positif; 2) $50 \% \leq \mathrm{RS}<70 \%$ maka respon siswa kurang positif; 3) $70 \% \leq \mathrm{RS}<85 \%$ maka respon siswa positif; 4) $85 \% \leq \mathrm{RS}$ maka respon siswa sangat positif.

\section{HASIL DAN PEMBAHASAN}

Fase pengembangan multimedia interaktif pada materi himpunan berbasis puzzle dengan pendekatan kontekstual antara lain sebagai berikut: 1) Fase analisis. Pada fase ini yang dilakukan adalah observasi atau pengamatan ke sekolah untuk mencari informasi tentang masalah yang dihadapi siswa pada mata pelajaran matematika; 2) Fase desain. Pada fase ini dirancang multimedia interaktif pada materi himpunan berbasis puzzle dengan pendekatan kontekstual. Pengembangan rancangan multimedia interaktif mengacu pada kurikulum yang digunakan, soal disajikan dalam bentuk permainan yang bersifat kontekstual sesuai dengan siswa SMP kelas 7, permainan yang dirancang terdiri dari materi yang disajikan dalam bentuk pertanyaan dan animasi, dan multimedia interaktif ini dilengkapi dengan materi, contoh soal, soal latihan, kunci jawaban serta nilai yang diperoleh siswa setelah mengerjakan soal.

Rancangan multimedia interaktif pada materi himpunan berbasis puzzle dengan pendekatan kontekstual dapat dilihat pada Gambar 2 sampai Gambar 7. Gambar 2 menampilkan halaman pembuka dimana pada halaman pembuka ini diberikan animasi, suara, maupun gambar yang menarik 
DOI: https://doi.org/10.24127/ajpm.v9i4.3132

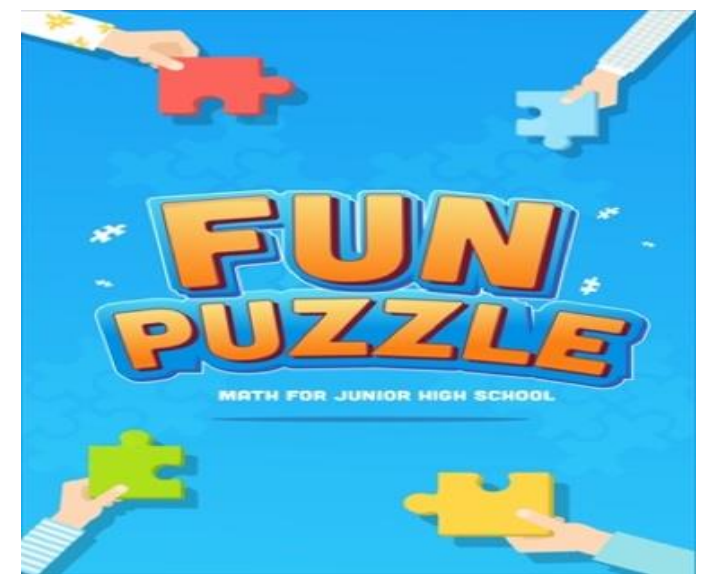

Gambar 2. Halaman pembuka.

Gambar 3 adalah halaman start. Tampilan pada halaman start adalah tombol start untuk memulai permainan.

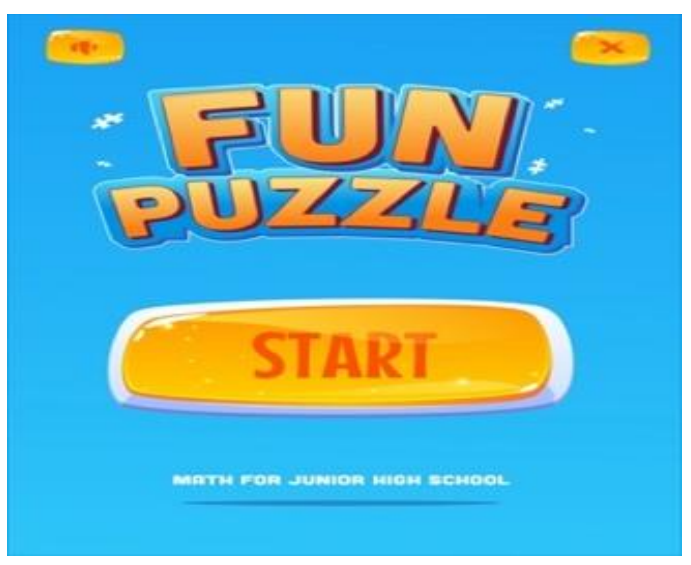

Gambar 3. Halaman Start.

Gambar 4 adalah halaman menu dimana halaman ini berisi jenis-jenis game yang bisa dimainkan.

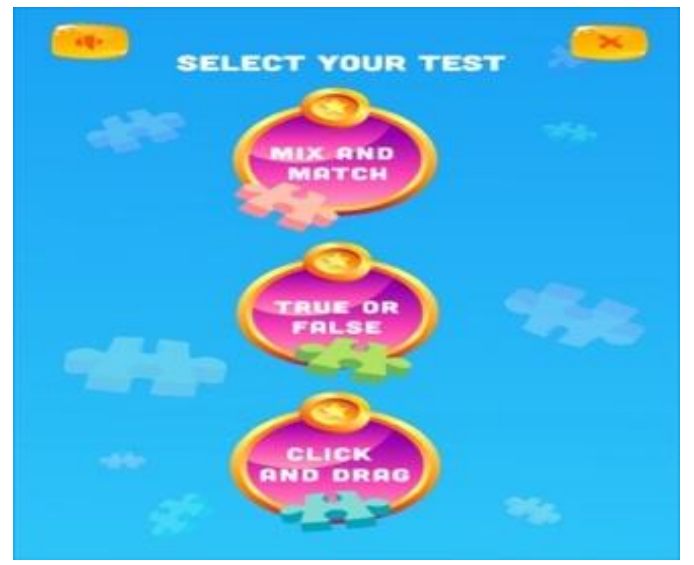

Gambar 4. Halaman Menu
Gambar 5 adalah halaman latihan dimana siswa diberikan soal latihan tentang himpunan dengan tujuan mengetahui tentang pemahaman siswa terhadap materi himpunan.

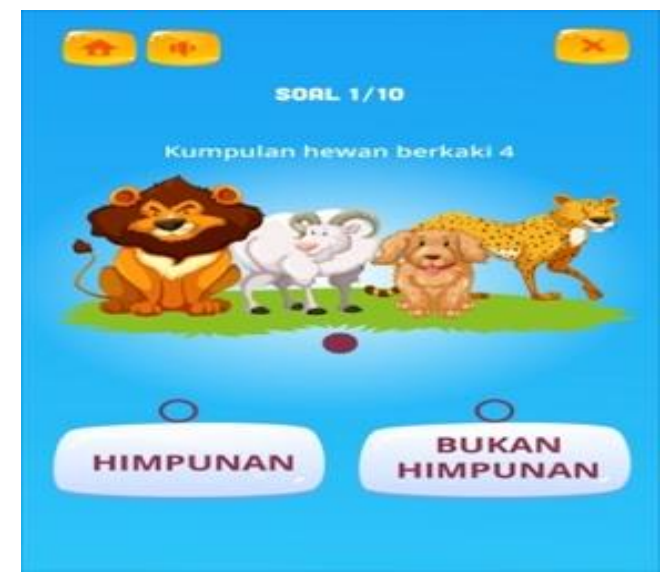

Gambar 5. Halaman Latihan.

Gambar 6 adalah halaman penilaian adalah halaman selanjutnya setelah siswa mengerjakan latihan soal. Pada halaman ini siswa dapat melihat apakah jawabannya benar atau salah.

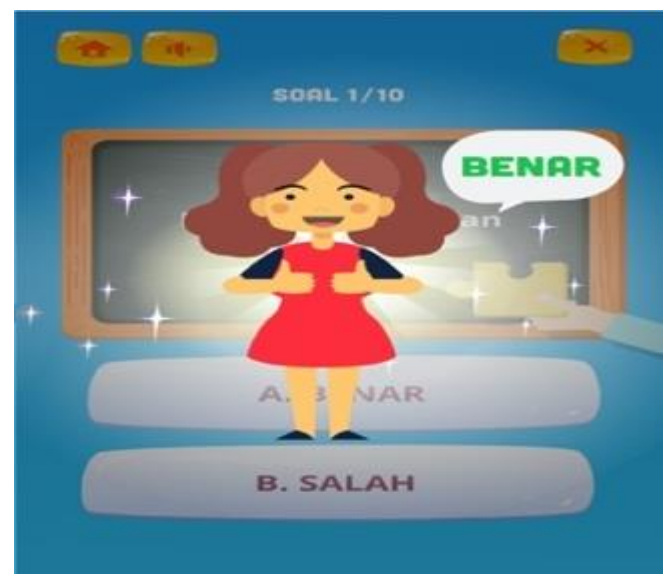

Gambar 6. Halaman Penilaian.

Gambar 7 adalah halaman nilai dimana menjadi halaman terakhir dari game yang diberikan sehingga siswa dapat langsung mengetahui nilai yang diperoleh setelah mengerjakan latihan soal. 


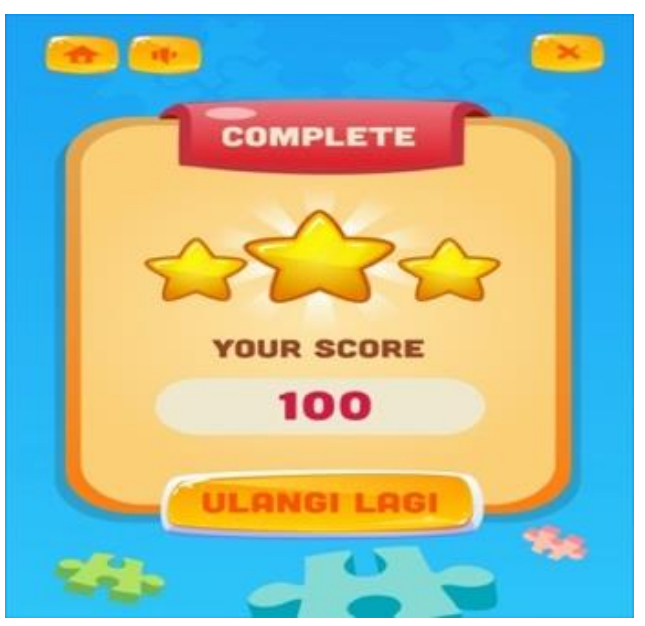

Gambar 7. Halaman Nilai.
3) Fase pengembangan. Pada fase ini yang dilakukan adalah mengembangkan multimedia interaktif berupa game pada materi himpunan berbasis puzzle dengan pendekatan kontekstual. Pada fase ini dilakukan validasi terhadap multimedia in teraktif yang dikembangkan. Adapun rekapitulasi hasil penilaian dari validator dapat dilihat pada Tabel 1 .

Tabel 1. Hasil rekapitulasi validator.

\begin{tabular}{|c|c|c|c|c|}
\hline No & Aspek & Indikator & $\overline{\boldsymbol{x}}_{\boldsymbol{t}}$ & Keterangan \\
\hline \multirow[t]{4}{*}{1} & Kelayakan Isi & $\begin{array}{l}\text { 1. Kesesuaian substansi materi } \\
\text { terhadap konsep himpunan } \\
\text { kelas } 7 \text { SMP }\end{array}$ & 3,3 & Valid \\
\hline & & $\begin{array}{l}\text { 2. Menampilkan masalah yang } \\
\text { kontekstual }\end{array}$ & 3,7 & Valid \\
\hline & & $\begin{array}{l}\text { 3. Soal yang ditampilkan pada } \\
\text { multimedia memberikan } \\
\text { rangsangan pada siswa } \\
\text { mengidentifikasi konsep } \\
\text { himpunan }\end{array}$ & 3 & Valid \\
\hline & & $\begin{array}{l}\text { 4. Aktivitas didalam multimedia } \\
\text { mendorong siswa untuk } \\
\text { membangun pemahaman dan } \\
\text { kemandirian. }\end{array}$ & 3,3 & Valid \\
\hline \multirow[t]{6}{*}{2} & $\begin{array}{l}\text { Kelayakan } \\
\text { Tampilan }\end{array}$ & $\begin{array}{l}\text { 5. Kemudahan dalam } \\
\text { pengoperasian multimedia }\end{array}$ & 3,7 & Valid \\
\hline & & $\begin{array}{l}\text { 6. Siswa dengan lancar dalam } \\
\text { beralih slide }\end{array}$ & 3,7 & Valid \\
\hline & & $\begin{array}{l}\text { 7. Terdapat kesesuaian dalam } \\
\text { tata letak, tulisan, ukuran } \\
\text { maupun gambar }\end{array}$ & 3 & Valid \\
\hline & & $\begin{array}{l}\text { 8. Kombinasi tulisan, warna, dan } \\
\text { gambar yang sesuai }\end{array}$ & 3,3 & Valid \\
\hline & & $\begin{array}{l}\text { 9. Menggunakan Bahasa } \\
\text { Indonesia yang baik dan benar }\end{array}$ & 3,7 & Valid \\
\hline & & $\begin{array}{l}\text { 10. Menariknya tampilan } \\
\text { multimedia }\end{array}$ & 3,3 & Valid \\
\hline
\end{tabular}


Hasil rata-rata ketiga validator menunjukkan nilai 3,40. Jadi rata-rata nilai validator adalah $85 \%$, maka sesuai dengan kategori multimedia interaktif ini valid digunakan. Indikator yang digunakan merupakan pengembangan dari teori pengembangan multimedia interaktif menurut (Albar, 2017).

4) Fase implementasi. Pada fase implementasi yang dilakukan adalah melakukan uji coba lapangan. Uji coba yang pertama adalah uji coba kelompok kecil dimana terdiri dari tiga orang siswa. Tujuan dari uji coba kelompok kecil adalah untuk menguji keterbacaan dari multimedia interaktif yang dikembangkan. Hasil dari uji coba kelompok kecil menunjukkan bahwa siswa lebih antusias untuk mempelajari materi himpunan serta siswa dengan kemampuan sedang dan rendah sulit mengerti pada soal mendaftar anggota himpunan. Dari uji coba kelompok kecil maka dianalisis dan direvisi kemudian dilakukan uji coba kelompok besar yang terdiri dari 25 siswa kelas 7 SMP Tarbiyatus Shyban.

5) Fase evaluasi. Pada fase ini yang dilakukan adalah menganalisis keefektifan dari multimedia interaktif yang dikembangkan. Analisis keefektifan terdapat dua kegiatan yang akan dinilai yaitu hasil belajar siswa dan respon siswa. Data hasil belajar siswa diambil setelah proses pembelajaran dengan multimedia interaktif seorang siswa dianggap tuntas atau menguasai materi yang diberikan jika mendapatkan skor minimal 75 dari skor maksimal 100. Adapun rekapitulasi hasil belajar siswa dapat dilihat pada Tabel 2.

Berdasarkan Tabel 2 terlihat persentase ketuntasan siswa adalah $78,2 \%$ maka sesuai dengan kriteria siswa memiliki tingkat penguasaan terhadap materi himpunan yang baik.
Data angket respon siswa adalah menilai bagaimana tingkat keefektifan dari multimedia interaktif yang dikembangkan. Indikator yang digunakan sebagai penilaian adalah menguji tingkat kesenangan atau ketertarikan siswa terhadap multimedia interaktif ini. Adapun rekapitulasi hasil angket respon siswa dapat dilihat pada Tabel 3.

Tabel 2. Rekapitulasi hasil belajar siswa

\begin{tabular}{cccc}
\hline No & Nama & P/L & $\begin{array}{c}\text { Tes } \\
\text { Ahkir }\end{array}$ \\
\hline 1 & ET & P & 85 \\
2 & RR & L & 65 \\
3 & DA & L & 80 \\
4 & AH & L & 75 \\
5 & AF & P & 50 \\
6 & AM & L & 80 \\
7 & FH & P & 85 \\
8 & MR & P & 75 \\
9 & NA & P & 75 \\
10 & PF & P & 80 \\
11 & TP & P & 85 \\
12 & UK & P & 65 \\
13 & IA & L & 75 \\
14 & AP & L & 90 \\
15 & BP & P & 80 \\
16 & BS & L & 80 \\
17 & DR & P & 85 \\
18 & DB & P & 80 \\
19 & FU & P & 75 \\
20 & KA & L & 80 \\
21 & MK & P & 80 \\
22 & MJ & P & 80 \\
23 & FP & P & 85 \\
24 & KF & L & 90 \\
25 & GA & P & 75 \\
\hline Persentase Skor rata-rata & $78,2 \%$ \\
Tuntas & & & $78,2 \%$ \\
Tidak Tuntas & & $21,8 \%$ \\
\hline
\end{tabular}


DOI: https://doi.org/10.24127/ajpm.v9i4.3132

Tabel 3. Rekapitulasi hasil angket respon siswa.

\begin{tabular}{lcl}
\hline Nama & $\overline{\boldsymbol{x}_{\boldsymbol{\imath}}}$ & Keterangan \\
\hline ET & 3,14 & Respon positif \\
RR & 3 & Respon positif \\
DA & 3,57 & Respon positif \\
AH & 3 & Respon positif \\
AF & 3,57 & Respon positif \\
AM & 3,57 & Respon positif \\
FH & 3 & Respon positif \\
MR & 3,43 & Respon positif \\
NA & 4 & Respon positif \\
PF & 3 & Respon positif \\
TP & 3,29 & Respon positif \\
UK & 3,71 & Respon positif \\
IA & 3 & Respon positif \\
AP & 3,71 & Respon positif \\
BP & 3,29 & Respon positif \\
BS & 3,43 & Respon positif \\
DR & 3 & Respon positif \\
DB & 3,43 & Respon positif \\
FU & 3,29 & Respon positif \\
KA & 3,71 & Respon positif \\
MK & 3,57 & Respon positif \\
MJ & 3,29 & Respon positif \\
FP & 3,43 & Respon positif \\
KF & 3,43 & Respon positif \\
GA & 3,57 & Respon positif \\
Total Rata- & \\
\multicolumn{1}{c}{ rata } & 3,38 \\
RS $(\%)$ & $84,5 \%$ \\
\hline \multicolumn{7}{r}{} & &
\end{tabular}

Berdasarkan Tabel 3, persentase respon siswa adalah $84,5 \%$ maka sesuai dengan kriteria siswa memberikan respon positif. Diskusi dari pengembangan multimedia interaktif pada materi himpunan berbasis puzzle dengan pendekatan kontekstual antara lain diuraikan sebagai berikut: terdapat kesesuaian multimedia interaktif yang dikembangkan dengan tujuan penelitian pengembangan ini. Tujuan utama dalam pengembangan multimedia interaktif ini adalah meningkatkan pemahaman siswa pada materi himpunan melalui media pembelajaran yaitu multimedia interaktif dimana didalam multimedia interaktif ini memuat materi himpunan, animasi yang menarik, suara, gambar, latihan soal, nilai yang diperoleh. Selain itu dapat meningkatkan motivasi siswa untuk belajar mandiri dan meningkatkan efektifitas pada proses pembelajaran.

Kelebihan dari multimedia interaktif pada materi himpunan berbasis puzzle dengan pendekatan kontekstual adalah materi himpunan menjadi menarik karna divisualisasikan melalui gambar maupun animasi, tampilannya disesuaikan dengan siswa kelas 7 SMP sehingga siswa mudah dalam mengoperasikan atau mengakses materi himpunan, multimedia interaktif ini menggunakan pendekatan kontekstual yang dikemas dalam bentuk game puzzle sehingga siswa dapat mempelajarinya secara mandiri dan dimanapun tidak terikat harus didalam kelas. Dapat disimpulkan bahwa multimedia interaktif pada materi himpunan berbasis puzzle dengan pendekatan kontekstual praktis dan efektif digunakan sebagai media pembelajaran untuk siswa. Hasil penelitian ini sejalan dengan penelitian yang dilakukan oleh (Akbar W., 2017; Purnomo, A, 2017; Istiqlal, 2017; Pranata et al., 2015). Dampak yang dihasilkan dari penelitian ini yaitu siswa menjadi senang belajar matematika khususnya pada materi himpunan yang dikembangkan ini.

\section{KESIMPULAN DAN SARAN}

Berdasarkan hasil penelitian dapat disimpulkan bahwa penelitian ini menghasilkan multimedia interaktif pada materi himpunan berbasis puzzle dengan pendekatan kontekstual, hasil dari rata-rata validatas ketiga validator menunjukkan kategori valid untuk diujicobakan. Setelah dilakukan ujicoba menunjukkan hasilnya siswa tuntas 
belajar dan siswa memberikan respon positif. Secara menyeluruh maka multimedia interaktif pada materi himpunan berbasis puzzle dengan pendekatan kontekstual efektif untuk digunakan dalam proses pembelajaran.

Saran untuk penelitian selanjutnya adalah multimedia interaktif yang dikembangkan perlu diujicobakan secara kontinu dalam proses pembelajaran untuk siswa SMP. Hal ini bertujuan untuk mengetahui tingkat penguasaan materi dan pemahaman siswa sehingga dapat diketahui sejauh mana kelayakan multimedia interaktif ini dapat digunakan sebagai sumber belajar baik secara mandiri maupun disekolah.

\section{DAFTAR PUSTAKA}

Akbar W. (2017). Pengembangan Multimedia Pembelajaran Matematika Untuk Siswa Kelas III SD Negeri percobaan 2 Yogyakarta. E-Jurnal Prodi Teknologi Pendidikan, 6(7), 673683.

Albar. (2017). Pengembangan Multimedia Interaktif Dalam Kontekstual Ditinjau Dari Pemahaman Konsep Siswa. Journal of Mathematics Education, Science and Technology, 2(2), 221-230.

Andinny, Y.,\& Lestari, I. (2016). Pengaruh Pembelajaran Multimedia Terhadap Hasil belajar Matematika. Jurnal Kajian Pendidikan Matematika, 1(2), 169179.

Arofah, R., \& Cahyadi, H. (2019). Pengembangan Bahan Ajar Berbasis ADDIE Model. Islamic Education journal, 3(1), 35-43. https://doi.org/10.21070/halaqa.v3i 1.2124
Clontz, S. (2018). Puzzle Types. Diakses dari http://clontz.org/puzzles/types/. pada tanggal 20 Oktober 2020, Jam 20.00 WIB.

Fauziah, S. Indah. (2019). Pengaruh Pendekatan Pembelajaran Kontekstual Berbasis Multimedia Terhadap Kemampuan Pemahaman Matematis Siswa SMP. Jurnal On Education, 1(2), 246-255.

Gray, P. (2011). The Decline of Play and the Rise of Psychopathology in Children and Adolescents. American Journal of Play, 3(4), 443-463.

Heru. (2018). Pengembangan Multimedia Game Pembelajaran matematika SMP. Jurnal Math Educator Nusantara, 4(1), 01-14.

Istiqlal, M. (2017). Pengembangan Multimedia Interaktif Dalam Pembelajaran Matematika. Jurnal Ilmiah Pendidikan Matematika, 2(1), 43-54.

Ivers, K. S. \& A. E. B. (2010). Multimedia projects in education: designing, producing, and assessing. Second Edition. LIBRARIES UNLIMITED Teacher Ideas Press.

Kurnia, A. (2015). Pengaruh Penggunaan Media Pembelajaran Visual terhadap Hasil Belajar Ekonomi Siswa X Semester Genap SMA Negeri 1 Pekalongan. Proseding Semnas Pendidikan Ekonomi \& Bisnis, November.

Kurniawati, I.D., \& Nita, S. (2018). Media Pembelajaran Berbasis Multimedia Interaktif Untuk Meningkatkan Pemahaman Konsep Mahasiswa. Journal of Computer and Information Technology, 1(2), 68-75. 
Milla, M. L., Patricia, F. A., \& Sari, R. K. (2018). Analisis Kesulitan Berpikir Visual Dalam Memahami Konsep Pada Materi Himpunan. Jurnal PRISMATIKA Vol. 1 No. 1.

Mulhamah. (2016). Penerapan pembelajaran kontekstual dalam meningkatkan kemampuan pemecahan masalah matematika 1). Jurnal Pendidikan Matematika, 10(1), 59-80.

Nopriyanti. (2015). Pengembangan Multimedia Pembelajaran Interaktif Kompetensi dasar pemasangan Sistem penerangan dan Wiring Kelistrikan Di SMK. Jurnal Pendidikan Vokasi, 5(1), 222-235.

Oxford University Press. (2017). English Oxford Living Dictionaries. Diakses dari https://en.oxforddictionaries.com/d efinition/puzzle. Pada tanggal 15 Juni 2020, Jam 14.00WIB.

Panjaitan, R.G.P, \& Titin. (2020). Multimedia Interaktif Berbasis Game Edukasi Sebagai Media Pembelajaran Materi Sistem Pernapasan Di Kelas XI SMA. Indonesian Journal of Science Education, 8(1), 141-151.

Pranata, S. A., Wardani, D. P., \& Pendidik, J. P. (2015). Diary of Dyscalculia Untuk Anak Berkesulitan Belajar Matematika. Jurnal Profesi Pendidikan, 2(2), 86-97.

Purnomo, A, D. (2017). Pengembangan Game Untuk Terapi membaca Bagi Anak Disleksia Dan Diskalkulia. Jurnal Simetris, 8(2), 497-506.

Rasyid, M., Azis, A. A., Saleh, A. R., Biologi, M. J., Makassar, U. N., Biologi, D. J., \& Makassar, U. N. (2016). Pengembangan Media Pembelajaran Berbasis
Multimedia. Jurnal Pendidikan Biologi, 7(2), 69-80.

Rejeki, T. S., Wulandari, R., \& Wijayanti, K. (2019). Meningkatkan Kemampuan Pemecahan Masalah Matematika Dan Percaya Diri Siswa Kelas VII SMPN 39 Semarang Melalui PBL Berbantuan Kartu Masalah. Jurnal PRISMA, 2(1), 770-777.

Rochmad. (2012). Desain Model Pengembangan Perangkat Pembelajaran Matematika. Jurnal Kreano, 3(1), 59-72.

Sugiyono. (2016). Metode Penelitian Kuantitatif, Kualitatif, dan $R \& D$. Bandung: Alfabeta.

Surachman, M. (2014). Pengembangan Multimedia Interaktif Berbasis Kontekstual Untuk Meningkatkan Penguasaan Konsep Dan Keterampilan Berpikir Kritis Siswa kelas XI Pada Materi Pokok Sistem Koloid. Jurnal Pijar, 9(2), 62-67.

Yunanto, S. H. (2016). " Smart Puzzle " Game Helping Children Learn to Read. Journal of Information System, 3(1), 13-19. 